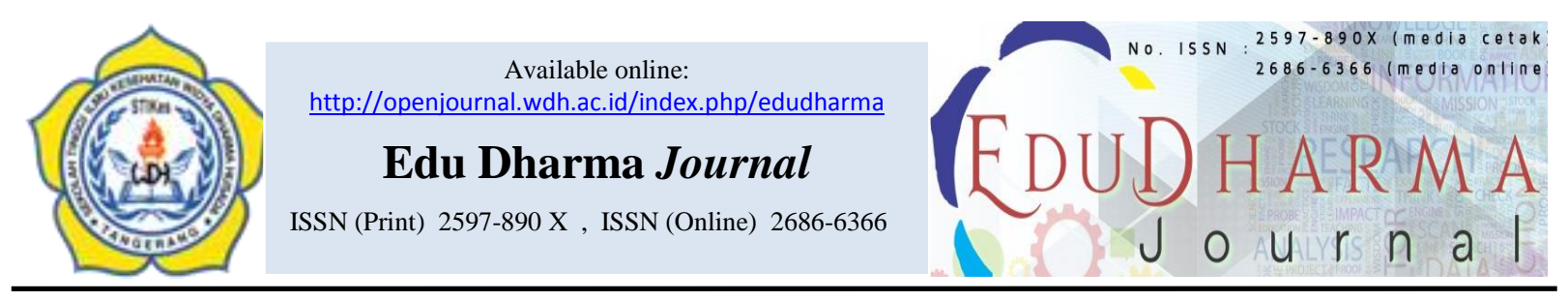

\title{
HUBUNGAN PENGETAHUAN DAN PERSEPSI TENTANG SEKSUALITAS PADA REMAJA DENGAN PERILAKU SEKS PADA SISWA KELAS XI JURUSAN AKUNTANSI DI SMK SASMITA JAYA 1 PAMULANG
}

\author{
Siti Novy Romlah ${ }^{1 *}$, Riris Andriati ${ }^{2}$, Hani Fauziah ${ }^{3}$ \\ ${ }^{1,2,3}$ STIKes Widya Dharma Husada Tangerang, Jalan Pajajaran No.1, Pamulang, Tangerang Selatan 15417, Indonesia
}

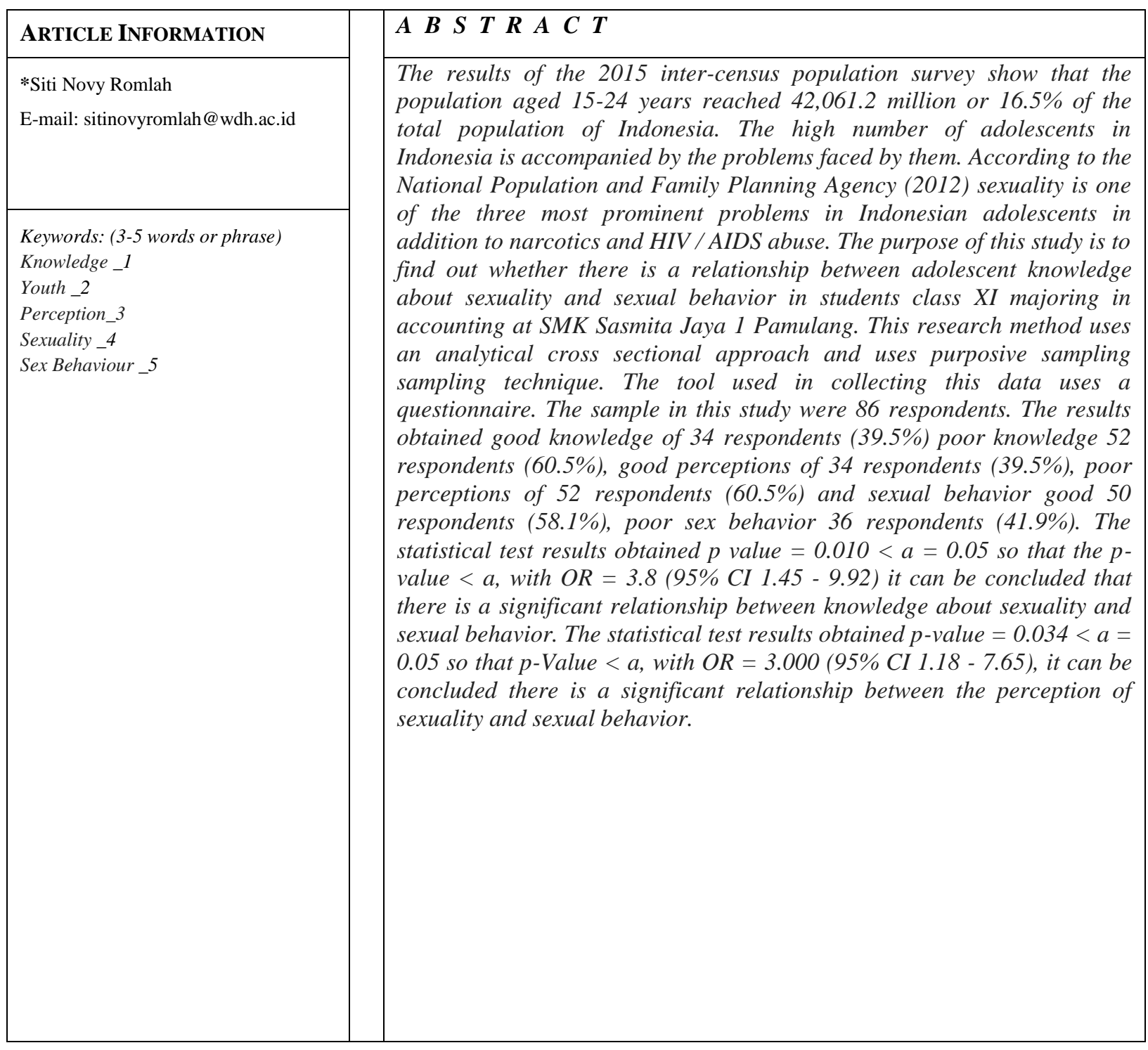




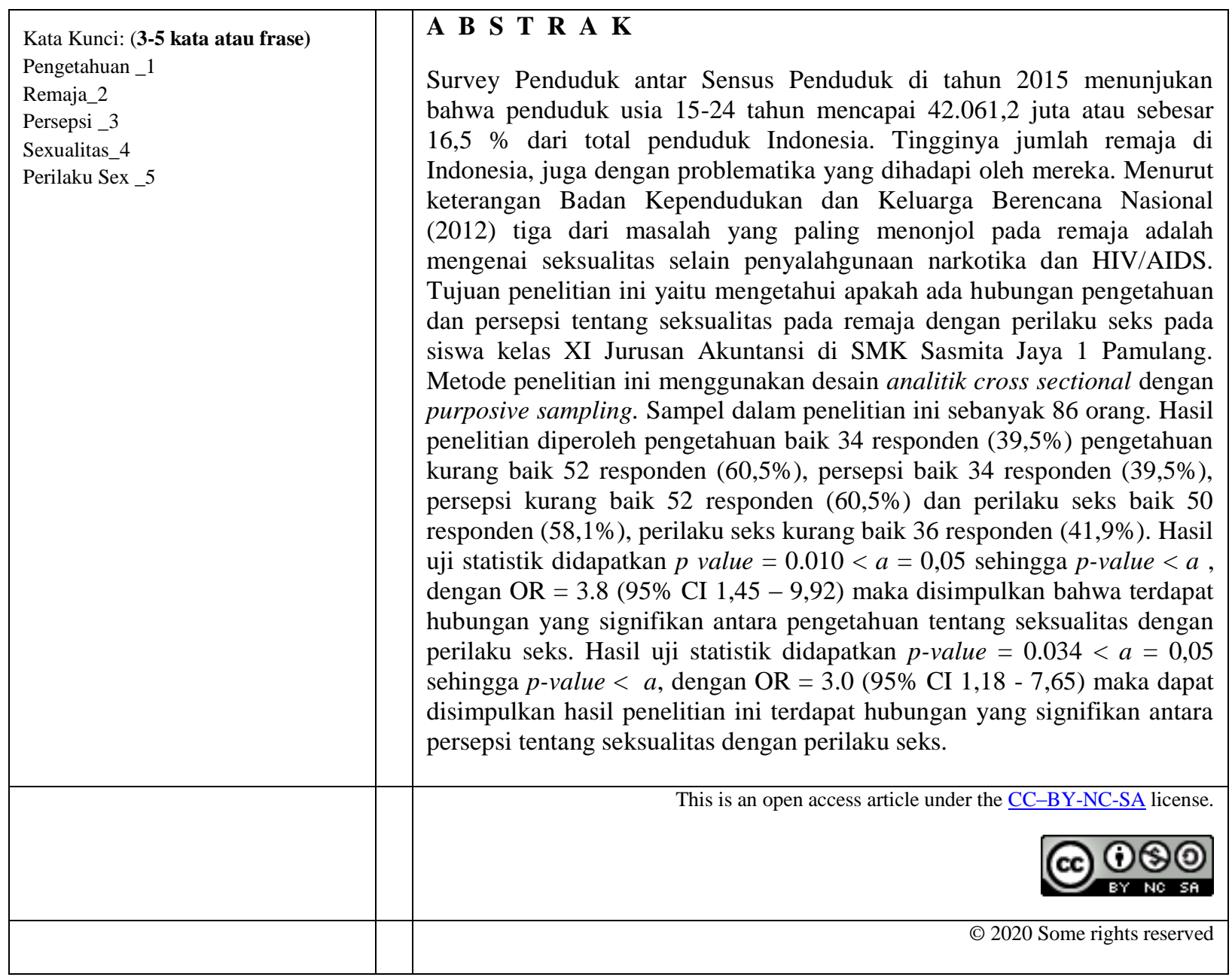




\section{PENDAHULUAN}

Menurut Kumalasari dan Andhyantoro (2012) pengetahuan seseorang tentang seksual yang benar dapat memimpin seseorang kearah perilaku seksual yang rasional dan bertanggung jawab serta dapat membantu membuat keputusan pribadi yang penting terkait seksualitas. Begitupun sebaliknya jika pengetahuan tentang seksual yang salah dapat mengakibatkan kesalahan persepsi tentang seksualitas sehingga selanjutnya akan menimbulkan perilaku seksual yang salah dengan akibatnya.

Hasil Sensus Penduduk tahun 2010, jumlah penduduk Indonesia 237,6 juta jiwa dimana sebanyak 63,4 juta diantaranya merupakan remaja, yang terdiri dari remaja laki-laki sejumlah 32.164 .436 juta $(50,70 \%)$ dan perempuan sebanyak 31.279.012 jiwa (49,30\%). Penduduk usia remaja perlu mendapatkan perhatian khusus mengingat remaja termasuk dalam usia sekolah dan usia kerja serta telah memasuki umur reproduksi dan dalam masa seksual aktif. Jika tidak dipersiapkan dengan baik menimbulkan resiko hubungan seksual pra nikah (BKKBN, 2011)

Dalam sebuah penelitian yang dilakukan Nugraha menunjukkan bahwa 10-20\% remaja memiliki timgkat pengetahuan seksualitas sangat kurang, sehingga menyebabkan remaja yang dalam perkembangan jasmaninya akan mempunyai dorongan seksual yang sangat kuat namun disisi yan berlainan remaja justru dijauhkan dari hal-hal yang berbau seksualitas. Demikian pula penelitian yang dilakukan Synovate menemukan bahwa sekitar $65 \%$ informasi tentang seks remaja dapatkan dari kawan dan juga 35\% sisanya dari film porno. Ironisnya hanya 5\% dari responden remaja yang mendapatkan informasi tentang seks dari orang tuanya. (Marliana, 2018)

Badan Kependudukan dan Keluarga Berencana Nasional (BKKBN, 2012) menemukan beberapa temuan terkait perilaku berpacaran remaja yang belum menikah yaitu sebanyak $29,5 \%$ remaja pria dan $6,2 \%$ remaja wanita pernah meraba atau merangsang pasangannya, sebanyak $48,1 \%$ remaja laki-laki dan $29,3 \%$ remaja wanita pernah berciuman bibir. Sebanyak $79,6 \%$ remaja pria dan $71,6 \%$ remaja pernah berpegangan tangan dengan pasangannya. Data BKKBN pun mengenai HIV/AIDS menemukan bahwa informasi HIV relative lebih banyak diterima oleh remaja, mekipun hanya $9,9 \%$ remaja perempuan dan 10,6\% laki-laki memiliki pengetahuan komperhensif mengenai HIV/AIDS. Semakin dini seseorang 
melakukan hubungan seksual, maka semakin berisiko untuk terinfeksi penyakit menular seksual, salah satunya HIV/AIDS. Mengenai tempat pelayanan remaja juga belum banyak diketahui oleh remaja. (BKKBN, 2012 dalam Asna, 2011)

Hasil studi pendahuluan yang telah dilakukan pada tanggal 30 April 2019 pada 15 responden didapatkan hasil pengetahuan siswa tentang seksualitas yang mempunyai pengetahuan baik hanya 3 orang (20\%) dan yang mempunyai pengetahuan kurang baik ada 12 orang (80\%). Persepsi siswa tentang seksualitas yang mempunyai persepsi baik 11 orang (73\%) dan persepsi kurang baik 4 orang (27\%). Perilaku seks yang dilakukan siswa yang baik ada 3 orang (20\%) dan perilaku seks yang kurang baik ada 12 orang (80\%). Perilaku seks yang sering dilakukan siswa mulai dari menonton film porno 9 orang (60\%), pernah memegang tangan 12 orang (75\%), pernah memeluk pacar 12 orang (75\%), pernah berciuman bibir 13 orang (87\%), pernah mencium sekitar leher kebawah 10 orang $(83 \%)$, dan informasi seks yang siswa dapat berasal dari keluarga 1 orang (7\%), teman 9 orang $(60 \%)$, internet 3 orang (20\%), guru 2 orang (13\%). Berdasarkan studi pendahuluan tersebut menjadi dasar dilakukannya penelitian pada siswa jurusan akuntansi di
SMK Sasmita Jaya 1 Pamulang. Penelitian ini dengan judul "Hubungan pengetahuan dan persepsi tentang seksualitas pada remaja dengan perilaku seks pada siswa kelas XI Jurusan Akuntansi di SMK Sasmita Jaya 1 Pamulang”.

\section{METODE PENELITIAN}

Penelitian ini menggunakan desain analitik dengan pendekatan cross sectional, yaitu sebuah penelitian dengan cara pengumpulan data yang dilakukan sekaligus pada suatu saat dimana subjek penelitian hanya diobservasi sekali saja dan pengukurannya dilakukan terhadap status karakter atau variable subjek pada saat pemeriksaan (Notoatmodjo, 2012).

Lokasi yang dipilih pada penelitian ini adalah di SMK Sasmita Jaya 1 Pamulang dengan subjek penelitian yaitu siswa kelas XI Jurusan Akuntansi. Waktu penelitian dimulai pada bulan April - Mei 2019 akan dilakukan pengumpulan data dan pengurusan administrasi pengumpulan data. Pengambilan sampel dalam penelitian ini menggunakan cara non probability sampling dengan teknik pursposive sampling yaitu teknik pengambilan sampel yang tidak memberikan peluang/kesempatan sama bagi setiap unsur anggota populasi untuk dipilih 
menjadi responden dan berdasarkan pada pertimbangan atau kriteria peneliti sesuai

\section{HASIL}

\section{Analisis univariat}

Tabel 1. Distribusi Frekuensi Responden Berdasarkan Usia siswa Kelas XI Jurusan Akuntansi di SMK Sasmita Jaya 1 Pamulang

\begin{tabular}{lcl}
\hline Usia & $(\mathrm{n})$ & $(\%)$ \\
\hline 16 & 33 & 38,37 \\
17 & 41 & 47,68 \\
18 & 8 & 9,30 \\
19 & 4 & 4,65 \\
\hline Total & 86 & 100 \\
\hline
\end{tabular}

Berdasarkan tabel 1 menunjukan bahwa usia responden hampir setengahnya yaitu pada usia 17 tahun $(47,68 \%)$ dan hampir tidak ada yang berusia 19 tahun $(4,65 \%)$.

Tabel 2. Distribusi Frekuensi Responden Berdasarkan Jenis Kelamin Kelas XI Jurusan Akuntansi di SMK Sasmita Jaya 1 Pamulang

\begin{tabular}{lll}
\hline Jenis Kelamin & $(\mathrm{n})$ & $(\%)$ \\
\hline Laki-laki & 25 & $29 \%$ \\
Perempuan & 61 & $71 \%$ \\
\hline Total & 86 & 100 \\
\hline
\end{tabular}

Berdasarkan tabel 2 menunjukan bahwa lebih dari setengahnya responden berjenis kelamin perempuan sebanyak 61 responden $(71 \%)$, sebagian kecil berjenis kelamin laki-laki sebanyak 25 responden $(25 \%)$. maksud dan tujuan (Fajar, dkk, 2009; Sugiyono, 2018).

Tabel 3. Distribusi Frekuensi Responden Berdasarkan Sumber Informasi Seks Kelas XI Jurusan Akuntansi di SMK Sasmita Jaya 1 Pamulang

\begin{tabular}{lll}
\hline Informasi seks & $(\mathrm{n})$ & $(\%)$ \\
\hline Keluarga & 5 & 5,81 \\
Temen & 52 & 60,46 \\
Internet & 17 & 19,78 \\
Guru & 12 & 13,95 \\
\hline Total & 86 & 100 \\
\hline
\end{tabular}

Berdasarkan tabel 3 menunjukan bahwa responden mendapatkan sumber informasi tentang seks lebih dari setengahnya berasal dari teman sebanyak 52 orang $(60,46 \%)$ dan hampir tidak ada berasal dari keluarga sebanyak 5 orang $(5,81 \%)$.

Tabel 4. Distribusi Frekuensi Responden Berdasarkan Pengetahuan tentang Seksualitas Kelas XI Jurusan Akuntansi di SMK Sasmita Jaya 1 Pamulang

\begin{tabular}{lll}
\hline Pengetahuan & $(\mathrm{n})$ & $(\%)$ \\
\hline Baik & 34 & 39,5 \\
Kurang baik & 52 & 60,5 \\
\hline Total & 86 & 100
\end{tabular}

Berdasarkan tabel 4 menunjukan bahwa hampir setengahnya pengetahuan baik sebanyak 34 responden $(39,5 \%)$, lebih dari setengahnya pengetahuan responden kurang baik sebanyak 52 responden $(60,5 \%)$ 
Tabel 5.Distribusi Frekuensi Responden Berdasarkan Persepsi tentang Seksualitas Kelas XI Jurusan Akuntansi di SMK Sasmita Jaya 1 Pamulang

\begin{tabular}{lll}
\hline Persepsi & $(\mathrm{n})$ & $(\%)$ \\
\hline Baik & 34 & 39,5 \\
Kurang baik & 52 & 60,5 \\
& & 100 \\
\hline Total & 86 & 100 \\
\hline
\end{tabular}

Berdasarkan tabel 5 menunjukan bahwa

kurang baik sebanyak 52 responden hampir setengahnya responden mempunyai $(60,5 \%)$.

persepsi yang baik sebanyak 34 responden

$(39,5 \%)$ lebih dari setengahnya persepsi

Tabel 6.Distribusi Frekuensi Responden Berdasarkan Kategori Perilaku Seks Kelas XI Jurusan Akuntansi di SMK Sasmita Jaya 1 Pamulang

\begin{tabular}{lcc} 
Perilaku seks & (n) & $(\%)$ \\
\hline Baik & 50 & 58,1 \\
Kurang baik & 36 & 41,9 \\
\hline Total & 86 & 100 \\
\hline
\end{tabular}

Berdasarkan tabel 6 menunjukan bahwa lebih dari setengahnya perilaku seks responden yang baik ada sebanyak 50 responden $(81,9 \%)$, hampir setengahnya perilaku kurang baik sebanyak 36 responden $(41,9 \%)$.

Tabel 7.Distribusi Frekuensi Responden Berdasarkan Pengetahuan dan Persepsi Tentang Seksualitas Dengan Perilaku Seks Kelas XI Jurusan Akuntansi di SMK Sasmita Jaya 1 Pamulang

\begin{tabular}{|c|c|c|c|c|c|c|c|c|}
\hline & & Perilak & ku sek & & & & $\mathrm{QR}$ & P Value \\
\hline & Baik & & Kuran & g baik & To & & OK & $P$ value \\
\hline & $\mathrm{N}$ & $\%$ & $\mathrm{~N}$ & $\%$ & $\mathrm{~N}$ & $\%$ & $95 \% \mathrm{CI}$ & \\
\hline & & & Penge & ahuan & & & & \\
\hline Baik & 26 & 76,5 & 8 & 23,5 & 34 & 100 & $\begin{array}{c}3.8 \\
(1,45-9,92)\end{array}$ & 0.01 \\
\hline Kurang baik & 24 & 46,2 & 28 & 53,8 & 52 & 100 & & \\
\hline & & & Perse & & & & & \\
\hline $\begin{array}{l}\text { Baik } \\
\text { Kurang baik }\end{array}$ & $\begin{array}{l}25 \\
\quad 25\end{array}$ & $\begin{array}{c}73,5 \\
48,1\end{array}$ & $\begin{array}{c}9 \\
27\end{array}$ & $\begin{array}{l}26,5 \\
51,9\end{array}$ & $\begin{array}{c}34 \\
52\end{array}$ & $\begin{array}{l}100 \\
100\end{array}$ & $\begin{array}{c}3.0 \\
(1.18-7.65)\end{array}$ & 0.034 \\
\hline
\end{tabular}


Berdasarkan tabel 7 dapat dilihat bahwa dari 86 responden yang memiliki pengetahuan tentang seksualitas baik dengan perilaku seks baik sebanyak 26 responden $(76,5 \%)$, pengetahuan tentang seksualitas baik dengan perilaku seks kurang baik sebanyak 23 responden $(23,5 \%)$, pengetahuan tentang seksualitas kurang baik dengan perilaku seks baik ada 24 responden $(46,2 \%)$, pengetahuan tentang seksualitas kurang baik dengan perilaku seks kurang baik sebanyak 28 responden $(53,8, \%)$.

Hasil uji statistik menunjukan bahwa didapatkan $p$-value $=0.010<a=0,05$ sehingga $p$-value < nilai $a$, dengan OR 3.8 $(95 \%$ CI 1,45 - 9,92) maka dapat disimpulkan bahwa terdapat hubungan yang signifikan antara pengetahuan tentang seksualitas dengan perilaku seks.

Berdasarkan tabel 7 analisa hubungan persepsi tentang seksualitas dengan perilaku seks pada siswa XI Jurusan Akuntansi dapat dilihat bahwa dari 86 responden yang memiliki persepsi tentang seksualitas baik dengan perilaku seks baik sebanyak 25 responden $(73,5 \%)$, persepsi tentang seksualitas baik dengan perilaku seks kurang baik sebanyak 9 responden $(23,5 \%)$, persepsi tentang seksualitas kurang baik dengan perilaku seks baik ada 25 responden $(46,2 \%)$, persepsi tentang seksualitas kurang baik dengan perilaku seks kurang baik sebanyak 27 responden (51,9\%). Hasil uji statistik didapatkan $p$ value $=0.034<a=0,05$ sehingga $p$-value $<$ nilai $a$, dengan $\mathrm{OR}=3.0(95 \%$ CI 1,18 7,65) maka dapat disimpulkan hasil penelitian ini terdapat hubungan yang signifikan antara persepsi seksualitas dengan perilaku seks.

\section{PEMBAHASAN}

\section{Pengetahuan Seksualitas}

Pengetahuan adalah sebuah hasil pengindraan manusia, atau hasil tahu seseorang terhadap objek melalui indra yang dimilikinya (mata, hidung, telinga, dan sebagainya) (Notoatmodjo, 2014). Dengan sendirinya pada waktu pengindraan menghasilkan pengetahuan tersebut sangat dipengaruhi oleh intensitas perhatian dan persepsi terhadap objek. Sebagian besar pengetahuan seseorang diperoleh melalui indra pendengaran (telinga), dan indra penglihatan (mata).

Berdasarkan hasil analisis menunjukan bahwa pengetahuan responden baik sebanyak 34 responden $(39,5 \%)$, dan pengetahuan kurang baik sebanyak 52 responden $(60,5 \%)$. 
Penelitian ini sejalan dengan penelitian Tetty (2015) dari 103 responden menunjukan bahwa sebagian besar pengetahuan baik 20 orang $(19,4 \%)$, cukup 30 orang $(29,1 \%)$, kurang 53 orang $(51,5)$.

Penelitian Nugraha menunjukkan bahwa $10-20 \%$ remaja memiliki pengetahuan seksualitas sangat kurang, sehingga dapat menyebabkan remaja yang dalam perkembangan jasmaninya akan mempunyai dorongan seksual yang sangat kuat namun disisi lain mereka justru dijauhkan dari hal-hal yang berbau seksualitas.

Pada penelitian ini disimpulkan bahwa tingkat pengetahuan seseorang dapat ditentukan dengan bermacam-macam tingkatan. Oleh sebab itu responden agar dapat meningkatkan pengetahuannya dengan cara mencari informasi mengenai seksual dari sumber yang benar yaitu dari guru, buku atau media lain yang dapat dipertanggungjawabkan, dapat juga di pelayanan-pelayanan kesehatan.

Semakin banyak informasi yang didapat diharapkan tingkat pengetahuan juga meningkat dan wawasan responden juga akan luas.

\section{Persepsi seksualitas}

Persepsi merupakan objek disekitar kita, ditangkap melalui alat-alat indra diproyeksikan pada bagian tertentu di otak sehingga kita dapat mengamati objek tersebut. Persepsi berlangsung saat seseorang menerima stimulus dari dunia luar yang ditangkap oleh organorgan bantuannya yang kemudian masuk kedalam otak (Prawirohardjo, 2011).

Berdasarkan hasil analisis dalam penelitian ini menunjukan bahwa responden mempunyai persepsi yang baik sebanyak 34 responden $(39,5 \%)$ dan persepsi kurang baik sebanyak 52 responden $(60,5 \%)$.

Penelitian ini sejalan dengan Atiek (2016) terdiri dari 85 responden yang mempunyai persepsi positif sebanyak 80 responden $(94,1 \%)$, persepsi negative 5 responden $(5,9 \%)$. Sehingga penelitian ini menyimpulkan bahwa persepsi yang didapatkan dari hasil penelitian mempunyai persepsi atau tanggapan tentang seksualitas yang kurang baik sebanyak 52 responden $(60,5 \%)$.

\section{Perilaku Seks}

Menurut Notoatmodjo (2014) perilaku merupakan semua kegiatan atau aktifitas manusia baik yang diamati 
langsung maupun tidak dapat diamati oleh pihak luar. Hal ini berarti bahwa perilaku terjadi apabila ada sesuatu yang diperlukan untuk menimbulkan reaksi yakni yang disebut rangsangan. Oleh karena itu suatu rangsangan tertentu akan menghasilkan reaksi perilaku tertentu.

Majalah porno, situs porno, film porno dapat membuat gejolak seks tidak menentu jika remaja tidak dapat mengendalikan diri, dimana remaja sangat mudah mengikuti lingkungan disekitarnya, apalagi dorongan rasa ingin tahu tentang seks yang besar dari remaja (Hurlock, 1999, dalam Marliani, 2016). Pengaruh teman pergaulan sangat bermacam-macam, mulai dari menyukai hal yang berhubungan dengan pornografi dan seksualitas,membicarakan pornografi dan seks, mengajak teman melihat video porno, mengajak kearah prostitusi, jika tidak mengikuti akan dikritik dan dikatakan ketinggalan.

\section{Hubungan Pengetahuan dan}

Persepsi tentang Seksualitas dengan

\section{Perilaku Seks}

Hasil penelitian ini sesuai dengan teori yang dikemukakan oleh Notoatmodjo bahwa pengetahuan merupakan domain yang sangat penting untuk
Hasil analisa dalam penelitian ini menunjukan bahwa perilaku seks responden yang menunjukan baik ada sebanyak 50 responden $(81,9 \%)$ dan perilaku kurang baik sebanyak 36 responden $(41,9 \%)$.

Penelitian ini sejalan dengan penelitian Tetty (2015) dari 103 responden yang mempunyai perilaku seks responden positif 68 orang (66\%), negative 35 orang (34\%). Adapun perilaku seks ini dipengaruhi oleh hormon-hormon seksual yaitu testosterone untuk laki-laki dan progesterone untuk wanita.

Peneliti menyimpulkan bahwa perilaku seks yang dilakukan oleh siswa yang menunjukan perilaku kurang baik sebanyak 36 responden $(41,9 \%)$ bisa dikarenakan faktor dari luar atau pergaulan yang dimana menerima informasi yang salah sehingga beberapa siswa terpengaruh oleh pergaulan yang membuat mereka berperilaku kurang baik.

terbentuknya tindakan seseorang. Pengetahuan seseorang tentang sesuatu objek juga mengandung dua aspek, yakni aspek negative dan positif. Kedua aspek inilah yang akhirnya menentukan sikap seseorang terhadap objek tertentu. Pengetahuan 
mungkin diperlukan sebelum terlaksananya suatu perilaku, akan tetapi perilaku yang diinginkan belum tentu terjadi kecuali orang tersebut memiliki motivasi yang kuat untuk terbentuknya sesuai dengan pengetahuan yang mereka miliki (Notoatmodjo, 2014).

Dasar terbentuknya pengetahuan yaitu melalui mta dan telinga manusia. Dari pengalaman dan penelitian membuktikan bahwa terbentuknya perilaku seseorang adalah predisposisi dari pengetahuan. Sebuah perilaku yang didasari oleh pengetahuan dia kan lebih bertahan lama dari pada perilaku yang tidak didasari oleh pengetahuan.

Dari hasil penelitian didapatkan yang memiliki pengetahuan tentang seksualitas baik dengan perilaku seks baik sebanyak 26 responden $(76,5 \%)$, pengetahuan tentang seksualitas baik dengan perilaku seks kurang baik sebanyak 23 responden (23,5\%), pengetahuan tentang seksualitas kurang baik dengan perilaku seks baik ada 24 responden (46,2\%), pengetahuan tentang seksualitas kurang baik dengan perilaku seks kurang baik sebanyak 28 responden $(53,8, \%)$, hasil uji statistic didapatkan

$p$-value $=0.010<a=0,05$ sehingga $p$ value < $a$, sehingga disimpulkan bahwa ada hubungan yang bermakna antara pengetahuan tentang seksualitas dengan perilaku seks, dimana Odds Ratio 3.8 (95\% CI 1,45 - 9,92).

Penelitian ini sejalan dengan Rahma (2018) menunjukan adanya hubungan yang bermakna antara pengetahuan seksualitas dengan perilaku seksual remaja pada siswa di SMA Negeri 1 Subang dengan $p=0,0 a=0,05$. Dalam penelitiannya menjelaskan perilaku seksual yang kurang baik di kalangan remaja erat kaitannya dengan pengetahuan remaja yang kurang tentang seksualitas. Penelitian Nugraha yang menyatakan bahwa 10$20 \%$ remaja pengetahuan seksualitasnya sangat kurang, sehingga dapat menyebabkan remaja yang dalam perkembangan jasmaninya akan mempunyai dorongan seksual yang sangat kuat namun disisi lain mereka justru dijauhkan dari hal-hal yang berbau seksualitas.

Penelitian ini juga sejalan dengan Wanrizy (2014) dengan hasil penelitian tingkat pengetahuan baik dan menunjukan sikap seksual baik sebanyak 58 orang $(60,4 \%)$, sedangkan yang memiliki tingkat 
pengetahuan kurang baik menjukkan sikap kurang baik 69 orang $(65,1 \%)$. Hasil uji statistic diperoleh nilai ( $p$ value $=0,000 \quad a: 0,05$, sehingga $p$ Value $<a$, maka dapat disimpulkan hasil penelitian ini terdapat hubungan yang signifikan antara tingkat pengetahuan remaja tentang pendidikan seks dengan sikap seksual Persepsi adalah objek disekitar kita yang ditangkap melalui alat indra untuk kemudian diproyeksikan pada bagian tertentu di dalam otak sehingga kita dapat mengamati objek tersebut. Persepsi ini akan terjadi saat seseorang menerima rangsangan dari dunia luar yang ditangkap oleh organ-organ bantuannya lalu kemudian masuk kedalam otak (Prawirohardjo, 2011).

Perkembangan seksual akan meningkatkan keinginan remaja tentang seks (Dianawati, 2003). Hal ini diperkuat apabila teman sebayanya di lingkungan mengatakan bahwa seks terasa nikmat, ditambah lagi dengan masuknya segala informasi yang tidak terbatas. Kondisi seperti ini semakin meningkatkan rasa penasaran tersebut yang pada akhirnya akan mendorong remaja untuk lebih jauh lagi melakukan berbagai macam percobaan sesuai yang di inginkannya. Hal-hal pranikah di SMK Sasmita Jaya 1 Pamulang.

Peneliti menyimpulkan pendidikan seks bagi remaja sangat penting untuk terhindar dari hal yang tidak diinginkan dan bisa memberikan wawasan yang luas dan memilahmilah hal apa yang harus kita lakukan dan yang dihindari.

yang menjadi penasaran remaja tentang seksual antara lain tertarik terhadap seksualitas, keinginan menonton video porno dan mencari informasi tentang seks.

Dari hasil penelitian didapatkan yang memiliki persepsi tentang seksualitas baik dengan perilaku seks baik sebanyak 25 responden (73,5\%), persepsi tentang seksualitas baik dengan perilaku seks kurang baik sebanyak 9 responden $(23,5 \%)$, persepsi tentang seksualitas kurang baik dengan perilaku seks baik ada 25 responden $(46,2 \%)$, persepsi tentang seksualitas kurang baik dengan perilaku seks kurang baik sebanyak 27 responden $(51,9 \%)$, hasil uji statistic didapatkan $p$-value $=0.034<a=0,05$ sehingga $p$-value $<a$, sehingga disimpulkan bahwa ada hubungan yang bermakna antara Persepsi tentang seksualitas dengan perilaku seks, 
dimana Odds Ratio $=3.0(95 \% \mathrm{CI}$ $1,18-7,65)$

Penelitian ini sejalan dengan Atiek (2016) yaitu yang dilakukan pada 85 responden. Hasil penelitian menunjukan bahwa pengetahuan remaja baik sebanyak 76 responden $(86, \%)$, pengetahuan cukup 9 responden (10,6\%), pengetahuan kurang 0

\section{KESIMPULAN}

1. Distribusi responden berdasarkan tingkat pengetahuan tentang seksualitas lebih dari setengahnya kurang baik sebanyak 52 responden $(60,5 \%)$ dan hampir setengahnya memiliki pengetahuan baik sebanyak 34 responden $(39,5 \%)$.

2. Distribusi responden berdasarkan persepsi tentang seksualitas hampir setengahnya yang mempunyai persepsi yang baik sebanyak 34 responden $(39,5 \%)$ dan lebih dari setengahnya memiliki persepsi kurang baik sebanyak 52 responden $(60,5 \%)$.

3. Distribusi responden berdasarkan perilaku seks sebagian besar responden yang menunjukan perilaku seks baik sebanyak 50 responden $(81,9 \%)$ dan hampir setengahnya perilaku seks kurang baik sebanyak 36 responden $(41,9 \%)$ responden $(0 \%)$. Persepsi remaja positif sebanyak 80 responden $(94,1 \%)$, persepsi negative 5 responden $(5,9 \%)$. Hasil perhitungan statistik menunjukan adanya hubungan antaran variable independen dengan variable dependen, dengan hasil chi-square 0,028 maka $\mathrm{p} \leq$ 0,05 dikatakan ada hubungan.

4. Hubungan pengetahuan dan persepsi tentang seksualitas pada remaja dengan perilaku seks pada siswa kelas XI Jurusan Akuntansi di SMK Sasmita Jaya 1 Pamulang didapatkan hasil pengetahuan kurang baik dengan perilaku seks baik ada 24 responden (46,2\%), pengetahuan tentang seksualitas kurang baik dengan perilaku seks kurang baik sebanyak 28 responden $(53,8, \%)$. Hasil uji statistik didapatkan $p$-value $=0.010 . a=0,05$ sehingga $p$-value $<a$, dengan OR 3.8 (95\% CI 1,45 - 9,92) maka dapat disimpulkan hasil penelitian ini terdapat hubungan yang signifikan antara pengetahuan tentang seksualitas dengan perilaku seks. Persepsi tentang seksualitas kurang baik dengan perilaku seks baik ada 25 responden $(46,2 \%)$, persepsi tentang seksualitas kurang baik 
dengan perilaku seks kurang baik sebanyak 27 responden $(51,9 \%)$. Hasil uji statistic didapatkan $p$-value $=0.034$. $a=0,05$ sehingga $p$-value $<a$, dengan OR $3.0(95 \%$ CI 1,18-7,65) maka dapat

\section{DAFTAR PUSTAKA}

Aritonang, Tetty. R. 2015. "Hubungan pengetahuan dan sikap tentang kesehatan reproduksi dengan perilaku seks pranikah pada remaja usia (15-17 tahun) di SMK Yadika 13 Tambun Bekasi”. Hal 1-7. Tanggal akses 12 Januari 2019. Jam 21:14.http://digilib.mercubuana.ac.i d.

Asna, K. 2011. "Hubungan antara pengetahuan dan sikap terhadap kesehatan reproduksi dengan perilaku seksual pranikah pada siswa di SMAN 14 Kota Semarang”. Hal 1-83. Tanggal akses 17 Januari 2019. Jam 14:25. http://lib.unnes.ac.id/7559/

Dianawati, A. 2003. "Pendidikan dan seks untuk remaja”. Jakarta : Kawan Pustaka

Fajar, I. dkk. 2009. "Statistik Untuk Praktisi Kesehatan". Yogyakarta : Graha Ilmu.

Kumalasari, I. dkk. 2012. "Kesehatan Reproduksi untuk Mahasiswa Kebidanan dan Keperawatan”. Jakarta : Salemba Medika.

Marliani, R. 2016. "Psikologi Perkembangan Anak dan Remaja". Bandung : CV Pustaka Setia.

Notoatmodjo, S. 2012. “Metode Penelitian Kesehatan”. Jakarta : Rineka Cipta. disimpulkan hasil penelitian ini terdapat hubungan yang signifikan antara persepsi seksualitas dengan perilaku seks.

.2014. "Ilmu Perilaku Kesehatan”. Jakarta : PT Rineka Cipta.

Pratiwi. Atiek. (2016). "Hubungan pengetahuan dengan persepsi remaja tentang seks pranikah kelas XI di SMA 1 Sewon Bantul". Hal 1-10. Tanggal akses $03 \quad$ Mei 2019 jam 22:40.http://digilib.unisayogya.ac.id/19 75/1/Naskah\%20Publikasi.pdf.

Prawirohardjo, S.. 2011. "Psikologi Remaja. Edisi Revisi”. Jakarta : Yayasan Bina Pustaka.

Rahma, M. 2018. "Hubungan antara pengetahuan sekasulitas dengan perilaku seksual remaja di SMAN 1 Subang". Jurnal bidan volume 5 no 01 januari 2018. pISSN 2477-3441 eISSN 2477-345X. hal 1-9. Tanggal akses 17 Januari 2019 jam 22:00.http://jurnal.ibijabar.org//hubunga n-antara-pengetahuan-seksualitasdengan-perilaku-seksual-remaja-di-smanegri-1-subang.

Rachmat, M. 2012. "Buku Ajar Biostatistik : Aplikasi Pada Penelitian Kesehatan”. Jakarta : EGC.

Sugiyono. 2018. "Metode Penelitian Pendidikan (pendekatan kualitataif, kuantitatif dan R\&D)”. Bandung : Alfabeta.

Wanrizy, dikarta. 2014. "Hubungan tingkat pengetahuan remaja tentang pendidikan seks dengan sikap seksual pranikah di SMK Sasmita Jaya 1 Pamulang”. 